\title{
Pengaruh Pelatihan Teknik Announcing Terhadap Peningkatan Kualitas Pemandu Acara (MC) Bagi Remaja Kampung Cerdas
}

\author{
Azhar Hutomo \\ Universitas Bina Sarana Informatika \\ e-mail: azhar.aoz@bsi.ac.id
}

\begin{abstract}
Cara Sitasi: Hutomo, A. (2019). Pengaruh Pelatihan Teknik Announcing Terhadap Peningkatan Kualitas Pemandu Acara ( MC ) Bagi Remaja Kampung Cerdas. Jurnal Komunikasi, 10(1), 83-88.
\end{abstract}

\begin{abstract}
Announcement technique learning is not only important for radio broadcasters and television show guides. But it can be given as early as possible to children and adolescents. This is because this technique can be used as a tool for developing self-confidence in socializing and speaking in any context. This study aims to determine the effect of Announcing Technical Training on Quality Improvement of MCs. This type of research is quantitative. The data source of this study is primary data using the Smart Village Youth Youth as a sample. Data were collected using saturated sampling with respondents as many as 30 youth youth. This study uses simple linear regression analysis. The findings of this study indicate that the Announcing Technical Training affects the Quality Improvement of Hosts (MC) for Smart Village Adolescents.
\end{abstract}

Keyword: announcing training techniques, quality guide (MC).

\section{PENDAHULUAN}

Manusia pada dasarnya diciptakan Tuhan dengan dua fungsi sebagai mahluk pribadi dan sosial. Sebagai mahluk sosial, maka manusia tak lepas dari kegiatan komunikasi dan berinteraksi dengan manusia lain. Bahkan penelitian di Amerika Serikat menunjukkan bahwa 70\% hidup manusia tak bisa lepas dari komunikasi. Komunikasi dilakukannya untuk mencapai konsepsi kebahagiaan mereka masing-masing dan juga memapankan hubungan bermakna dengan orang lain.

Manusia tidak dapat hidup tanpa bantuan orang lain semenjak dilahirkan ke dunia hingga berkembang menjadi pribdi dewasa dan bekerja di lingkungan sosial. Salah satu dampaknya adalah penting bagi kita untuk berbicara dan bergaul dengan orang lain. Dalam berbicara dan bergaul dengan orang lain, penting pula bagi kita memahami bagaimana memproduksi suara dan vokal yang baik. Dalam dunia penyiaran, pembelajaran tentang seni produksi suara dan public speaking ini dikenal dengan teknik announcing.

Pembelajaran teknik announcing bukan hanya penting bagi penyiar radio dan pemandu acara televisi saja. Namun dapat diberikan sedini mungkin pada kalangan anak-anak dan remaja. Hal itu dikarenakan teknik ini dapat dijadikan mereka sebagai bekal pengembangan percaya diri dalam bergaul dan berbicara di depan umum pada konteks apapun. Entah untuk perannya sebagai pemandu acara, pembicara dalam seminar maupun sebagai pemimpin rapat dalam diskusi formal dan informal.

Fakta yang terjadi sekarang, masih banyak ditemukan remaja yang mengalami kesulitan untuk menghadapi kegiatan public speaking. Salah satu modal yang belum dimiliki untuk piawai dalam public speaking ini adalah teknik announcing. Kata dasar "Announce" ini dalam bahasa latin berasal dari kata "ad annuantiare" (mengumumkan). Menurut Ben G. Henneke and Edward S. Dumit (1959) Annnouncing adalah usaha untuk mengkomunikasikan informasi untuk memberikan sesuatu. Meskipun informasi itu dapat mencapai jutaan pendengar namun ditujukan kepada pendengar secara perorangan dan komunikasi itu akan sempurna apabila si pendengar mengerti,merasa tertarik lalu melakukan apa yang didengar itu.

Sementara kata dasar dari kata ad annuntiare adalah nuntius yang berarti pembawa pesan. Oleh karena itu dalam arti luas, "Announcing” ini diartikan sebagai usaha kita sebagai manusia untuk mengkomunikasikan informasi kepada orang lain agar mengerti dengan motif komunikasi kita sebagai komunikator dan mereka merasa tertarik 
untuk mendengar uraian penyampaian kita. Menurut Harold D Lassweell (1948) Komunikasi itu untuk merubah tingkah laku atau menimbulkan efek tertentu.

Untuk membuat orang lain tertarik mendengar uraian penyampaian pesan kita, bukanlah hal yang mudah. Selain penampilan, diperlukan pengetahuan dasar tentang teknik produksi suara,pengelolaan vokal yang benar, intonasi, artikulasi, pengaturan volume suara, tekanan kata ( word phrassing dan stressing), aksentuasi dan pertimbangan materi informasi yang disampaikan itu sendiri.

Tidak hanya berhenti disitu, terkadang dunia perkantoran sulit untuk menemukan orang yang tepat dalam menjadi juru bicara pada kegiatan resmi kedinasan. Acara tersebut seperti menjadi MC (Master of Ceremony) dalam ulang tahun organisasi, penyambutan visitasi dari dinas pemerintah terkait, acara peresmian pembangunan dan seremonial tertentu. Akhirnya, solusi yang dilalui suatu kantor tak jarang menyewa jasa MC atau event organizer tertentu untuk mengatasi hal itu. Keputusan ini berujung pada biaya yang tidak sedikit untuk dianggarkan dalam satu acara. Kurangnya pemberdayaan publik internal untuk mengisi tenaga public speaker ini menjadi titik tolak permasalahan yang kami angkat.

Pendidikan soft skill tentang seni berbicara di depan umum makin perlu diterapkan ke semua lini karyawan untuk menjawab permasalahan di atas. Selain itu, bertujuan untuk efektivitas anggaran yang akan dikeluarkan kantor atau organisasi, dengan memaksimalkan potensi sumber daya manusianya sendiri yang akan ditempatkan menjadi juru bicara atau MC. Permasalahan lain terjadi saat acara hiburan dan public figure kini di Indonesia makin melupakan etika public speaking saat memandu acara atau saat menjawab pertanyaan dari teman teman media massa. Belum lagi dalam teknik announcing yang ditunjukkan mereka cenderung mengandalkan "Keras" dan "Lantang" saja tanpa memandang situasi acara yang dihadapinya. Kekhawatiran terjadi, hal tersebut menjadi stimulus atau contoh buruk bagi masyarakat awam untuk menirunya, bahkan menganggapnya wajar dan makin melupakan teknik announcing yang baik dalam public speaking.

Saat ini, masyarakat harus menyadari bahwa kepiawaian dalam public speaking dan teknik announcing menjadi modal tersendiri untuk menunjang penampilan. Kepiawaian ini akan didapatkan karena persiapan yang cukup, memperkaya diri dengan budaya literasi atau membaca, memperkaya diri dengan perbendaharaan kosakata, terus latihan berbicara dan selalu meningkatkan wawasan kita dengan selektif memilih dan memilah informasi media massa. Kemahiran dalam public speaking akan membuat pribadi manusia menjadi lebih percaya diri, mudah bergaul, dan positif diterima oleh masyarakat.

Memang tak sedikit orang dapat berkata-kata tanpa berpikir namun tidak ada orang yang dapat berpikir tanpa kata-kata. Persiapan adalah kunci jawabannya. Berbicara tentang persiapan, maka diperlukan kampanye untuk mengedukasi masyarakat tentang tips dan trick untuk menjadi public speaker handal dengan teknik announcing yang baik.

Di sinilah kampanye pelatihan teknik announcing dalam menunjang kualitas pemandu acara bagi remaja berperan penting dalam kehidupan masyarakat.

Oleh karena itu penulis tertarik untuk meneliti dengan tujuan untuk mengetahui pengaruh Pelatihan Teknik Announcing Terhadap Peningkatan Kualitas Pemandu Acara.

Enam Kunci Utama Teknik Pengutaraan (Belajar Broadcast, rizkirprod.blogspot.com/2010)

a. $\mathrm{P}=$ Phrasing

Phrasing adalah Pembagian / pemenggalan kata dalam sebuah kalimat. Tujuannya adalah untuk mempermudah pendengar menerima pesan dengan jelas, tepat, tanpa keraguan.

Contoh :

- Kucing makan ikan mati

- Pegawai baru masuk kantor baru mulai jam 10.00 pagi.

- Selamat malam pendengar RRI Jakarta hari ini memasuki usianya yang ke 55 tahun.

b. $\mathrm{A}=$ Articulation

Kejelasan pengucapan huruf, suku kata ataupun kata

HURUF (Konsonan / Vokal)

Misalnya :

- Varia \& Paria

- Fakta \& Pakta

- Indonesia : Endonesya / Endoneisya SUKU KATA

Misalnya :

- Telah \& tengah

- Malam \& malang KATA

Misal :

- Debirokratisasi

- Kesejahteraan

- Keleluasaan

c. $\mathrm{S}=$ Speed

Kecepatan ujaran berdasarkan Panduan adalah (110 - 130) kata per menit.

Yang perlu diperhatikan adalah

- Lambat Monoton 
- Cepat Tidak peduli, tidak tertarik/tidak paham pada apa yang disampaikan

d. $\quad$ S = Stressing

Arti ada tiga, pertama Memberi tekanan pada kata-kata yang dimaksud

Misalnya :

- Pak Mulya telah menulis tiga buah buku pelajaran fisika

Kedua, Memperlambat penucapan kata yang dimaksud.

Misalnya :

- Anehnya ketika bentrokan itu terjadi, aparat keamanan justru meninggalkan tempat tersebut

Ketiga, Memperlama pause atau berhenti sebelum dan sesudah kata tersebut diucapkan

Misalnya :

- Setelah dia pergi, baru saya merasa........betul-betul....... kehilangan

e. I = Intonation Intonation adalah Tinggi rendah, irama, lagu kalimat.

Tujuannya adalah untuk Menghindari monoton, kejenuhan, mempermudah pengertian. Adapun Panduan yang digunakan :

- Gaya berbicara sehari-hari yang wajar.

- Sesuaikan dengan konteks kalimat. CATATAN

- Dalam praktek teknik pengutaraan antara stressing dan intonasi tidak dapat dipisahkan / saling berpengaruh membentuk gaya (ciri-khas) penyampaian.

f. $P=$ Pause

Pause artinya adalah Istirahat sejenak

Bagi seorang Presenter :

- Ambil Nafas.

- Melirik baris berikut.

Bagi seorang Pendengar :

Memperoleh kesempatan untuk memahami apa yang disampaikan, terutama dalam kalimat - kalimat panjang

Pengertian Announcer adalah Orang Yang menyajikan materi siaran kepada Pendengar. Menurut Asep Syamsul M. Romly (2009) Announcer (Penyiar) adalah ujung tombak radio. Mewakili radio, ia berinteraksi langsung dengan pendengar. Dengan kata lain penyiar adalah penampil yang melakukan pekerjaan penyiaran, menyajikan produk komersial, menyiarkan berita, akting sebagai pembawa acara atau bahkan menjadi pelawak, menjadi pewawancara , memandu diskusi kuis atau bahkan menjadi Narator.

Menjadi penyiarpun sesungguhnya memiliki syaratsyarat umum yang mesti dimiliki yaitu:

a. Mempunyai Kualitas vocal yang memadai

b. Mampu melakukan Script Reading yang baik

c. Memperlihatkan simpati dan emphati kepada Pendengar

d. Kreatif dan selalu berusaha memberikan ide segar dalam siaran

e. Mampu bekerja sama dengan team

f. Memiliki Gaya Bicara yang baik dan pengucapan yang cermat

g. Kepribadian suara yang khas dan tidak dibuat buat

Kerangka Berpikir

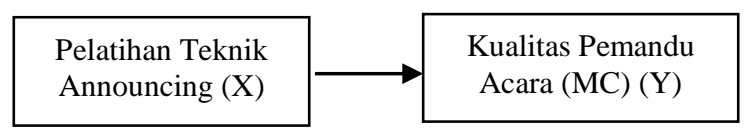

Gambar Kerangka Berpikir

Hipotesis Penelitian (Sugiyono, 2013) menyatakan bahwa "Hipotesis adalah alternatif dugaan jawaban yang dibuat oleh peneliti bagi problematika yang diajukan dalam penelitiannya”. Dugaan jawaban tesebut merupakan kebenaran yang sifatnya sementara, yang akan diuji kebenarannya dengan data yang dikumpulkan melalui penelitian. Dengan kedudukan itu maka hipotesis dapat berubah menjadi kebenaran, tetapi juga dapat tumbang sebagai kebenaran.

Selain itu, "Hipotesis adalah pernyataan dugaan (conjectural) tentang hubungan antara dua variabel atau lebih (Kerlinger, 2006). Hipotesis selalu mengambil bentuk kalimat pernyataan (declarative) dan menghubungkan secara umum maupun khususvariabel yang satu dengan variabel yang lain. Adapun hipotesis dalam penelitian ini adalah sebagai berikut :

$\mathrm{H}=$ Variabel Pelatihan Teknik Announcing (X) berpengaruh terhadap Kualitas Pembawa acara (MC)

\section{METODE PENELITIAN}

1. Gambaran Populasi

Menurut (Arikunto, 2010) mendefinisikan populasi yaitu "Populasi adalah keseluruhan dari subjek penelitian. Jadi yang dimaksud populasi adalah 
individu yang memiliki sifat yang sama walaupun prosentase kesamaan itu sedikit, atau dengan kata lain seluruh individu yang akan dijadikan sebagai obyek penelitian”. Jumlah populasi yang akan diteliti dalam penulisan ini adalah remaja karang taruna pengurus Yayasan Kampung Cerdas Indonesia dengan rentang umur 16 tahun s.d 25 tahun sebanyak 30 orang

\section{Sampel}

Menurut (Sugiyono, 2013) "sampel adalah sebagian dari jumlah dan karakteristik yang dimiliki oleh populasi tersebut. Untuk menentukan jumlah sampel dilakukan sebuah sampling. Teknik sampling merupakan teknik pengambilan sampel”.

\section{Teknik Pengambilan Sampel}

Metode pengambilan sampel yang dilakukan adalah dengan menggunakan metode Sampling Jenuh (Sugiyono, 2013) yaitu Seluruh Populasi menjadi sampel. Jadi jumlah sampel sebanyak 30 orang

4. Uji Instrumen Penelitian

a. Uji Validitas

Menurut Juliansyah (2012) "Validitas atau keabsahan adalah suatu indeks yang menunjukkan alat ukur tersebut benar-benar mengukur apa yang diukur. Validitas ini menyangkut akurasi instrumen”. Uji Validitas digunakan untuk mengukur sah atau valid tidaknya suatu kuesioner. Suatu kuesioner dikatakan valid jika pertanyaan pada kuesioner mampu mengungkapkan sesuatu yang akan diukur oleh kuesioner tersebut.

Kriteria penilaian uji validitas adalah:

1) Apabila Signifikansi variabel > Signifikansi 0,05, maka kuesioner tersebut tidak valid.

2) Apabila Signifikansi variabel < Signifikansi 0,05, maka kuesioner tersebut dikatakan valid.

b. Uji Reliabilitas

Menurut Arikunto (2010) Reliabilitas menunjuk pada suatu pengertian bahwa sesuatu instrumen cukup dapat dipercaya untuk digunakan sebagai alat pengumpul data karena instrumen tersebut sudah baik. Tujuannya adalah untuk menilai kestabilan ukuran dan konsistensi responden dalam menjawab kuesioner.

Kriteria pengujian reliabilitas sebagai berikut:

1) Apabila hasil koefisien Alpha lebih besar dari tahap signifikansi 60\% atau 0,6 maka kuesioner tersebut reliabel.

2) Apabila hasil koefisien Alpha lebih kecil dari taraf signifikansi $60 \%$ atau 0,6 maka kuesioner tersebut tidak reliabel.

\section{Regresi Linier Sederhana}

Teknik ini digunakan bila peneliti bermaksud meramalkan bagaimana keadaan (naik turunnya) variabel dependen, bila hanya ada satu variabel independen sebagai faktor prediktor dimanipulasi (dinaik turunkan nilainya). Jadi analisis regresi sederhana akan dilakukan bila jumlah variabel independennya hanya satu (Riduwan, 2009). Rumusnya adalah:

$$
\hat{Y}=a+b_{1} X
$$

\section{Keterangan:}

$\hat{\mathrm{Y}}=$ Kualitas Pemandu Acara (MC)

a = Bilangan Konstan

$\mathrm{b}=$ Koefisien Regresi

$\mathrm{X}$ = Skor variabel Pelatihan Teknik Announcing

\section{Pengujian Hipotesis}

a. Uji Koefisien Pengaruh (t)

Uji parsial ini dilakukan untuk mengetahui pengaruh Pelatihan Teknik Announcing dengan Kualitas Pemandu Acara (MC). Proses penilaiannya menggunakan software SPSS. Kaidah pengujian Signifikasi :

1) jika nilai signifikansi t $<0,05$ maka $\alpha, \mathrm{H}_{0}$ ditolak dan $\mathrm{H}_{1}$ diterima (signifikan).

2) jika nilai signifikansi t $>0,05$ maka $\alpha, \mathrm{H}_{0}$ diterima dan $\mathrm{H}_{1}$ ditolak (non signifikan).

\section{HASIL DAN PEMBAHASAN}

Dilihat dari profil responden penelitian ini, responden gender laki-laki lebih besar dari responden perempuan yaitu sebesar $65 \%$ untuk responden laki-laki dan 35\% untuk responden perempuan, sedangkan untuk usia mayoritas 21-25 Tahun sebanyak 60\%.

1. Uji Validitas dan Reliabilitas Indikator Penenelitian

Tabel 1. Variabel dan dimensi penelitian

\begin{tabular}{c|l}
\hline Variabel & Dimensi \\
\hline \multirow{4}{*}{ Pelatihan } & Phrasing \\
\cline { 2 - 2 } Teknik & Articulation \\
\cline { 2 - 2 } Announcing & Speed \\
\cline { 2 - 2 } & Stressing \\
\cline { 2 - 2 } & Intonation \\
\cline { 2 - 2 } & Pause \\
\hline \multirow{2}{*}{ Kualitas } & Vokal \\
\cline { 2 - 2 } Pemandu & Kreatif \\
\cline { 2 - 2 } Acara (MC) & Gaya Bicara \\
\cline { 2 - 2 } & Kepribadian \\
\hline
\end{tabular}

Hasil Uji Validitas dengan menggunakan SPSS dari pernyataan variabel Pelatihan Teknik Announcing (X), dan Kualitas Pemandu Acara (MC) (Y) pada kuesioner menunjukkan bahwa nilai signifikan (2tailed) kurang dari 0,05 untuk keseluruhan 
pernyataan, maka dapat diambil kesimpulan bahwa semua butir pernyataan adalah valid.

Tabel 2. Hasil Uji Reliabilitas Instrumen

\begin{tabular}{clcc}
\hline No & \multicolumn{1}{c}{ Variabel } & Alpha & Keterangan \\
\hline 1 & Pelatihan & 0,617 & Reliabel \\
& $\begin{array}{l}\text { Teknik } \\
\text { Announcing }\end{array}$ & & \\
\hline 2 & $\begin{array}{l}\text { Kualitas } \\
\text { Pemandu Acara } \\
\text { (MC) }\end{array}$ & 0,623 & Reliabel \\
\hline
\end{tabular}

Sedangkan koefisien alpha cronbach $>0,60$, berarti kuesioner yang disebarkan terhadap peserta training adalah sah artinya pertanyaan-pertanyaan pada kuesioner mampu mengungkapkan apa yang diukur oleh kuesioner tersebut, dan handal karena jawaban tiap responden dianggap konsisten atau stabil dari waktu ke waktu.

\section{Analisis Regresi Linear Sederhana}

Perhitungan regresi linier sederhana digunakan untuk memprediksi besarnya hubungan antara variabel terikat (dependen) yaitu Kualitas Pemandu Acara (MC) (Y), dengan variabel bebas (independen) yaitu Pelatihan Teknik Announcing (X). Hasil regresi linier sederhana dapat dilihat dibawah ini :

Tabel 3 Hasil Uji Regresi Sederhana Coefficients $^{\mathrm{a}}$

\begin{tabular}{|c|c|c|c|c|}
\hline \multirow[t]{2}{*}{ Model } & \multicolumn{2}{|c|}{$\begin{array}{l}\text { Unstandardized } \\
\text { Coefficients }\end{array}$} & \multirow[t]{2}{*}{$\mathrm{t}$} & \multirow[t]{2}{*}{ Sig. } \\
\hline & B & $\begin{array}{l}\text { Std. } \\
\text { Error }\end{array}$ & & \\
\hline 1 (Constant) & 8,433 & 2,676 & $\begin{array}{l}3,15 \\
2 \\
\end{array}$ & $\begin{array}{l}0,00 \\
4 \\
\end{array}$ \\
\hline $\begin{array}{l}\text { Pelatihan } \\
\text { Teknik } \\
\text { Announcing }\end{array}$ & 0,469 & 0,161 & 2,917 & $\begin{array}{l}0,00 \\
7\end{array}$ \\
\hline
\end{tabular}

Dari hasil pengolahan data diperoleh koefisien regresi dari tabel diatas sebagai berikut :

$\hat{\mathrm{Y}}=8,433+0,469(\mathrm{X})$

Dari hasil persamaan regresi linier sederhana diatas maka dapat diketahui bahwa :

a. Nilai konstanta 8,433, artinya jika Pelatihan Teknik Announcing (X), bernilai nol, maka nilai Kualitas Pemandu Acara (MC) (Y) sebesar 8,433 .

b. Koefisien regresi variabel Pelatihan Teknik Announcing (X) menunjukan nilai positif yaitu 0,469 . Hal ini menunjukan bahwa variabel Pelatihan Teknik Announcing (X) berpengaruh positif terhadap peningkatan Kualitas Pemandu Acara (MC) (Y), artinya semakin rutin Pelatihan Teknik Announcing $\left(\mathrm{X}_{1}\right)$ akan menyebabkan semakin meningkatnya pula Kualitas Pemandu Acara (MC) (Y).

3. Pengujian Hipotesis

a. Uji Hipotesis t

Pengujian hipotesis ini untuk mengetahui apakah variabel independen (Pelatihan Teknik Announcing) berpengaruh sendiri-sendiri terhadap variabel terikat (Kualitas Pemandu Acara (MC))

\begin{tabular}{|c|c|c|c|c|}
\hline \multicolumn{5}{|c|}{$\begin{array}{c}\text { Tabel } 4 \text { Hipotesis t } \\
\text { Coefficients }^{\mathrm{a}}\end{array}$} \\
\hline \multirow{2}{*}{\multicolumn{2}{|c|}{ Model }} & $\begin{array}{l}\text { Standardized } \\
\text { Coefficients }\end{array}$ & \multirow[t]{2}{*}{$\mathrm{t}$} & \multirow[t]{2}{*}{ Sig } \\
\hline & & Beta & & \\
\hline \multirow{4}{*}{1} & (Constant) & & 4,546 & 0,004 \\
\hline & Pelatihan & & 2,917 & 0,007 \\
\hline & Teknik & ,483 & & \\
\hline & Announcing & & & \\
\hline
\end{tabular}

Dari hasil Uji t dari tabel 4 menujukkan bahwa terdapat 1 variabel independen $(\mathrm{X})$ yaitu Pelatihan Teknik Announcing mempunyai pengaruh yang signifikan terhadap variabel dependen (Y) yaitu variabel Pelatihan Teknik Announcing $(\mathrm{X})$.

Untuk variabel Pelatihan Teknik Announcing $\left(\mathrm{X}_{1}\right)$ memiliki nilai signifikansi 0,007. Nilai Sig $\mathrm{t}<5 \%$ $(0,007<0,05)$. Dengan demikian pengujian Ho ditolak dan Ha diterima. Hal ini memperlihatkan bahwa Pelatihan Teknik Announcing (X) berpengaruh signifikan terhadap Kualitas Pemandu Acara (MC) (Y). Adapun besarnya pengaruh adalah sebesar 0,483 .

4. Keterbatasan Penelitian

a. Penelitian ini hanya terbatas pada Pelatihan Teknik Announcing. Diharapkan peneliti peneliti berikutnya melakukan penelitian dengan objek yang berbeda

b. Penelitian yang kami lakukan terbatas pada Pelatihan Teknik Announcing untuk menilai Kualitas Pemandu Acara (MC)

Berdasarkan penelitian ini pelatihan teknik Announcing untuk remaja kampung cerdas Cimanggis, Depok, Jawa barat terkait pelajaran dari enam kunci utama teknik pengutaraan seperti soal phrasing, articulation, speed, stressing, intonation 
dan pause perlu pelatihan yang rutin dan serius agar menghasilkan vokal dan kualitas suara yang baik.

Sementara itu untuk menjadi pemandu acara (MC) yang baik perlu memiliki teknik announcing yang bagus yang diperoleh melalui pelatihan-pelatihan yang rutin dan serius oleh remaja kampung cerdas.

\section{KESIMPULAN}

1. Kesimpulan

Berdasarkan hasil analisis dan pembahasan mengenai pengaruh Pelatihan Teknik Announcing terhadap kualitas pemandu acara (MC) maka dapat ditarik kesimpulan bahwa Variabel Pelatihan Teknik Announcing berpengaruh positif dan signifikan terhadap kualitas pemandu acara (MC)

2. Saran - saran

a. Karang Taruna kampung cerdas perlu meningkatkan pengetahuan dan ketrampilan para remajanya khususnya mengenai teknik announcing untuk meningkatkan kemampuan para remaja ketika ingin menjadi pemandu acara (MC)

b. Penelitian mendatang sebaiknya menggunakan objek penelitian yang berbeda maksudnya karang taruna daerah yang lain.

c. Penelitian mendatang sebaiknya menambahkan variabel lain yang mempengaruhi Kualitas pemandu acara (MC) seperti pelatihan pernapasan

\section{REFERENSI}

Arikunto, S. (2010). Prosedur penelitian: Suatu Pendekatan Praktik. Jakarta: Rineka Cipta.

Bungin, B. (2010). Metodologi Penelitian Kuantitatif. Jakarta: Kencana Prenada Media Group.
Ben G. and Dumit E. (1959). Announcer's Handbook. New York: Published by Holt Rinehart and Winston

Ferdinand, Augusty. 2006. Metode Penelitian Manajemen. Semarang: BPUNDIP

Kerlinger. (2006). Asas-Asas Penelitian Behaviour (3rd ed.). Yogyakarta: Gadjah Mada University Press.

Lasswell, H. D. (1948) Structure an Function of Communication in Society. New York: Published Harper and Brothers

Romly, Asep (2009) Dasar-dasar Siaran Radio Basic Announcing, Bandung: Nuansa Cendikia

Sekaran, U. (2012). Research Methods for Business. Jakarta: Salemba Empat.

Sugiyono. (2013). Metode Penelitian Kuantitatif, Kualitatif dan R\&D (19th ed.). Bandung: CV Alfabeta.

Umar, H. (2003). Riset Pemasaran \& Perilaku Konsumen. Jakarta: PT Gramedia Pustaka Utama.

http://rizkirprod.blogspot.com/2010/03/anouncingpart-1.html

\section{PROFIL PENULIS}

Azhar Hutomo S.Sos, M.si adalah dosen di Universitas Bina Sarana Informatika sejak bulan September 2016. Menyelesaikan jenjang pendidikan Strata Satu (S1) di Institut Ilmu Sosial dan Ilmu Politik Jakarta (IISIP) Jakarta tahun 1998, Fakultas Ilmu Komunikasi Jurusan Jurnalistik dan sudah menyelesaikan jenjang pendidikan Strata dua (S2) Magister Ilmu Komunikasi pada Universitas Sahid Jakarta tahun 2011. Selain aktif mengajar, Penulis masih bekerja di News Jaktv. 